\title{
Т.В. Алтухова
}

Кемеровский государственный университет

\section{Соотношение элементов устной и письменной речи в виртуальной коммуникации}

Аннотация: В статье рассматриваются стилевые особенности общения в Интернете. Освещена проблема соотношения элементов устной и письменной речи в Интернет-общении. Рассмотрены причины появления элементов устной речи и ее роли в повседневном виртуальном общении. Высказывается мнение о доминирующем положении письменной речи в Интернете.

The article deals with the stylistic features of Internet communication. The author elucidates the problem of the correlation of oral and written speech elements in internet communication, examines the reasons for the emergence of oral speech and its role in everyday speech, and expresses her own opinion of the dominant position of written speech on the Internet.

Ключевые слова: естественная письменная речь, письменная разговорная речь, устная речь, Интернет-коммуникация.

Natural written speech, written speaking, spoken language, Internetcommunication.

УДК: 81-114.2.

Контактная информация: Кемерово, ул. Красная, 6. КемГУ, факультет филологии и журналистики. Тел. (3842) 582745. E-mail: louvenna@mail.ru.

Многие ученые сходятся на мысли, что Интернет-коммуникация представляет собой гибрид устной и письменной речи [Капанадзе, 2005, с. 305-323; Кронгауз, 2009], который, будучи по способу фиксации речью письменной (визуальной), по многим характеристикам является устной.

Данная точка зрения имеет достаточно долгую (относительно истории изучения Интернета) традицию. В своей книге Д. Кристал отмечает, что в англоязычном пространстве Сети данная позиция поддерживается не только исследователями виртуального пространства, но и рядовыми пользователями, что отражается в руководствах по поведению в Интернете, таких как «Wired Style» [Crystal, 2001].

В отечественной Интернет-лингвистике данное мнение мы находим в работах Е. Буториной, Г.Н. Трофимовой, Л.А. Капанадзе, Б.А. Кутузова, М.Ю. Касумовой, М.А. Кронгауза, А. Данилеца.

В 2010 году была защищена диссертация на тему «Взаимодействие устной и письменной формы существования языка в Интернет-коммуникации», основанная на данном подходе. Ее автор, С.А. Лысенко, высказывает мнение, что в Интернет-коммуникации происходит «орализация языка», выражающаяся в «отражении устной речи средствами письменного языка», что приводит к фактическому доминированию устной речи в Интернете [Лысенко, 2010, c. 58]. По мнению

(C) Т.В. Алтухова, 2012 
исследователя, устно-письменная речь в Сети явилась результатом попытки передать особенности разговорной речи графическим способом [Лысенко, 2010, с. 55].

Главный тезис, лежащий в основе нашего видения специфики речи в Интернете - принципиальное различие каналов связи - аудиального и визуального. При определенном сходстве виртуальной коммуникации с устной, говорить о полном тождестве нельзя, так как Интернет-коммуникация использует визуальный канал связи, а значит, является письменной. И анализируя работы, настаивающие на том, что речь в Интернете является по сути устной, зафиксированной средствами письменного языка, мы находим определенное противоречие с точки зрения каналов, используемых при сетевой коммуникации.

А. Данилец в своей лекции разделяет Интернет-коммуникацию по форме на общение устное - при помощи голосового модема - и письменное - передача текстов и графики [Данилец]. С.А. Лысенко также выделяет опосредованную устную речь, передаваемую при помощи специальных технических средств [Лысенко, 2010, с. 36-37], кроме того, говорит о существовании устной речи, передаваемой посредством письменной. В первом случае устная речь является устной по способу фиксации, а во втором - по стилистической окраске. Таким образом, мы подходим к основной проблеме - какой признак лежит в основе оппозиции устный / письменный.

Е.А. Земская в основу определяющих факторов устной речи положила ее необратимость и неподготовленность [Земская, 1979, с. 54]. При таком подходе устная речь может фиксироваться средствами письменной, так как параметр первичной формы воплощения языка в данном определении не указывается. Оппозиция устная / письменная форма фиксации становится практически идентична стилевой оппозиции разговорный / книжный [Лысенко, 2010, с. 9].

Мы придерживаемся иной точки зрения. Вслед за В.В. Виноградовым, мы считаем оппозицию устный / письменный самостоятельной, лишь частично пересекающейся с оппозицией книжности / разговорности [Виноградов, 1955, с. 78].

Главный признак, влекущий за собой все основные особенности устной и письменной типов речи - форма материального воплощения и канал восприятия текста (слуховой или зрительный). Именно форма материального выражения позволяет письменной речи выполнять ее основные функции: материальную фиксацию, накопление и хранение информации, передача ее в пространстве и времени.

Форма фиксации речи обусловливает и ее особенности, в том числе затрудненность выражения эмоционального и модального компонентов в письменной речи и наличие паравербальных компонентов в устной речи, а также скорость протекания устной коммуникации и возможность корректировать речь по ходу контакта в зависимости от реакции адресата.

Соответственно, мы считаем, что более адекватным термином для обозначения языковой разновидности, используемой в Интернете, отражающей ее особенности, будет «письменная разговорная речь». Данный термин уже употреблялся в статье Т.Ю. Виноградовой и А.В. Кузнецова, в обоих случаях - по отношению к онлайн-общению. Такое обозначение кажется нам наиболее корректным, так как фиксирует стилевые особенности виртуальной коммуникации и при этом отражает форму ее фиксации.

Отметим также, что письменная разговорная речь, несомненно, заимствует некоторые элементы устной речи, что, однако, не делает ее лишь фиксацией, расшифровкой последней. Д. Кристал отметил, что четырем признакам устной речи (временные ограничения, спонтанность, социальное взаимодействие, слабая структурированность текста) язык Интернета отвечает только с оговорками «с ограничением», а признаки непосредственность общения, богатство интонации и возможность мгновенной корректировки, по мнению исследователя, вообще не задействованы в Интернет-общении [Crystal, 2001, p. 42]. 
Обратимся к рассмотрению фреймов устной речи в Интернет-коммуникации. М.А. Кронгауз справедливо отмечает, что если большая часть коммуникации переходит в область письма (как это произошло в Интернет-общении), неизбежно возникает вопрос о недостаточности письменной речи, что влечет за собой процесс ее обогащения [Кронгауз]. Но изобретать новые фреймы для передачи эмоций, логического ударения не требовалось: они уже были выработаны устной коммуникацией: громкость, интонация, выделение фрагментов речи голосом, мимика и жесты, Интернет-коммуникация лишь нашла способы передачи их в письменной речи.

Интонация, громкость, выделение голосом, акцент в Интернеткоммуникации передаются при помощи следующих графических приемов: изменение регистра, например: ЛЮЮЮдИ!!! ЗДЕСЬ ХОТЬ КТО-НИБУДЬ БЫ ра для части фразы / слова, например это НЕлогично; или разряженным шрифтом

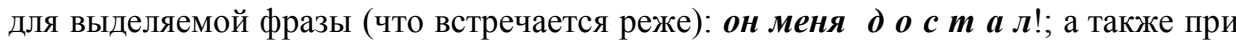
помощи знаков экспрессивной пунктуации и других символов на клавиатуре: !!!Мда... Интонация передается при помощи эмоциональной пунктуации: увеличение количество вопросительных, восклицательных знаков, многоточий: Какая красота!!!// да... Ну не ангельским, но ...ах!!

Для передачи акцента или особенностей произношения конкретного слова коммуниканты используют фонетическую (звуковую) запись выбранного фрагмента, или «звуковое письмо» [Трофимова, 2001]. Часто это проявляется в намеренном искажении графического облика слова (че, чевой то, наскока) или увеличении количества повторяющихся букв в слове: Не поливай гррррязью мою бессмертную любовь! // Оообооожеее!!!)) Дарт Мол, красааавец))).

Мимика, жесты. Эти паравербальные средства устной коммуникации передаются двумя способами: при помощи смайликов и обозначением в звездочках действие или эмоцию, например: *слюна прожигает пол*. Смайлики используются для двух типов ситуаций. Первая, когда коммуникант хочет показать, что его слова сказаны с улыбкой, имеют дружественные намерения, или указать эмоциональную направленность фразы, тогда он, как правило, ограничивается простым смайлом: улыбкой, грустью: $\wedge \wedge, ;))),=((\boldsymbol{t m}$ и т.д. если же нужно сопроводить фразу более точным изображением эмоций, которые она должна передавать или включить эмотиконы в языковую игру, пользователь употребляет более сложные наборы символов, например t_t ”, @_@ и т.д. Кроме того, использование японской системы смайликов используется для идентификации себя как члена определенной субкультуры.

Эти средства активно включаются в речь участников Интернеткоммуникации, преимущественно в разговорных жанрах (блоги, чаты, социальные сети, форумы). Однако их широкое использование не дает права утверждать, что речь в виртуальном общении является лишь графической расшифровкой устной речи и что устная речь является доминирующей формой общения в Интернете. Для того чтобы письменная речь была фиксацией устной, должно происходить проговаривание текста перед его записыванием, чего, как отмечает С.А. Лысенко в Интернет-коммуникации не происходит [Лысенко, 2010, с. 56].

Остановимся на феномене звукового письма, которое описывают как доказательство примате устной речи в Интернет-коммуникации. Однако, на наш взгляд, звуковое письмо, кроме фиксации особенностей произношения, также содержит в себе игру с графическим обликом слова, что возможно только в условиях письменной коммуникации и является одним из ее приемов. Появление большого количества повторяющихся букв в междометии иииииии хаaаaаa вовсе не свидетельствует о том, что пользователь вопит, сидя за своим компьютером. Таким образом, не происходит предварительного использования фреймов устного выражения смыслов и эмоций - используются сразу письменные, для передачи напи- 
санного через зрительный канал общения. Строго говоря, данный феномен находится в сфере пересечения двух тенденций. Одна из них - передача звуковой (устной) формы слова, а другая - эксперимент и игра с графическим обликом слова. Наши наблюдения свидетельствуют о том, что вторая тенденция является доминирующей. Звуковое письмо нередко используется для компрессии текста, что приводит к экономии усилий - и, как следствие, экономии времени и увеличения скорости реакции. К данным примерам можно отнести встречающиеся в Рунете написания типа куданить, ченить и под., в англоязычном пространстве - $\boldsymbol{u}$ вместо уоu, $\boldsymbol{r}$ вместо are, thnx вместо thanks, bcz, coz вместо because.

Но, кроме заимствования фреймов устной речи для обогащения своего арсенала, письменная сетевая коммуникация выработала свои собственные, графические и вербальные, способы выразительности и передачи смыслов, которые не всегда соотносятся с устной коммуникацией.

В статье М.А. Кронгауза приводятся некоторые из них: игра в зачеркивание, игра с языковыми раскладками. Игра с языковыми раскладками, которая породила слова типа йцукен, лытдыбр, зы. И это самые известные, однако, в качестве ников и обращений можно встретить образования Lheu (друг) ghbdtn (привет): например, в названии дневника GHBDTN///Я НОВЕНЬКАЯ:-).

Укажем также еще несколько приемов.

Использование в качестве высказываний непроизносимые (непроговариваемые, несловесные) компоненты, выражаемые числовыми знаками, например $+\mathbf{1},+500$ (которые позже могут трансформироваться в образования типа плюсnицот); состоящие из одних пунктуационных знаков: !!!, .... Порой пользователи создают целые рисунки, используя знаки стандартной клавиатуры.

Игра с цветовым решением (шрифта и фона) и регистром (который не всегда обозначает изменение интонации, например ПРеВеД, поКОЗАлось). Различные текстовые выделения также несут смысловую нагрузку (в том числе указание на значимые части текста или высказывания) и призваны способствовать достижению коммуникативной цели, однако делают это, не соотносясь прямо с фреймами, выработанными в устной коммуникации.

Подытоживая вышесказанное, заметим, что особенности Интернет-общения, связанные с привнесением элементов устной речи, связаны в первую очередь с изменением условий общения, а именно с обретением субстратом новых возможностей. Виртуальная коммуникативная среда преодолевает географические и временные границы, что делает возможным мгновенный обмен сообщениями из любой точки планеты. Увеличившаяся скорость общения уже не позволяет четко продумать, а иногда и проговорить текст, перед тем как написать его. Это влечет за собой увеличение доли синтаксических конструкций, характерных для устного разговорного стиля, повышает уровень спонтанности и неподготовленности текста, а также позволяет увеличить объем коммуникации, практически (хотя и не совсем) сравняв его удельный вес с объемом коммуникации в устном разговоре, что приводит к деформализации общения. В свою очередь, это приводит к необходимости вырабатывать новые способы для адекватной передачи смысла. И так как подобные способы уже выработаны в устной речи (соответствующие жесты, мимика, интонационные фреймы), виртуальная коммуникация лишь разработала средства их передачи. При этом, как справедливо указал А.В. Кузнецов, способ взаимодействия остается письменным [Кузнецов].

\section{Литература}

Буторина Е. А поговорить? Интернет как лингвистический феномен. [Электронный ресурс]. Режим доступа: http://www.gramota.ru/ biblio/magazines/gramota/net/28_50. Дата обращения - 21.12.2011. 
Виноградов В.В. Итоги обсуждения вопросов стилистики // Вопросы языкознания. 1955. № 1. С. 60-87.

Виноградова Т.Ю. Специфика общения в Интернете. [Электронный ресурс]. Режим доступа: http://septemberfox.ucoz.ru/biblio/vinogradova.html. Дата обращения - 21.12.2011.

Данилец А. Общение в чатах. Лекция. [Электронный ресурс]. Режим доступа: http://otrru.ru/Lekzii/ObshvChat.htm. Дата обращения - 21.12.2011.

Земская Е.А. Русская разговорная речь: лингвистический анализ и проблемы обучения. М., 1979.

Капанадзе Л.А. Голоса и Смыслы. Избранные работы по русскому языку. M., 2005.

Касумова М.Ю. Дискурс как объект междисциплинарного исследования // Язык. Текст. Дискурс. Научный альманах. Ставрополь, 2009. Вып. 7. С. 81-86.

Кронгауз М.А. «Лытдыбр» от блогера или как интернет-язык делает письменную речь формой существования разговорного языка. [Электронный ресурс]. Режим доступа: http://www.russkiymir.ru/russkiymir/ru/magazines/archive/2009/06/ article008.html. Дата обращения - 21.12.2011.

Кузнецов А.В. Письменная разговорная речь в онлайн-коммуникации // Молодой ученый. 2011. № 3. Т. 2. С. 24-26.

Кутузов Б.А. Коммуникативные особенности дискурса компьютерных сетевых форумов // Третьи Лазаревские Чтения: Традиционная культура сегодня: теория и практика: В 3 ч. Челябинск, 2006. Ч. 3.

Лысенко С.А. Взаимодействие устной и письменной формы существования языка в интернет-коммуникации: Дис. ... канд. филол. наук. Воронеж, 2010.

Трофимова Г.Н. Заходите в наш портал. [Электронный ресурс]. Режим доступа: http://www.gramota.ru/biblio/magazines/gramota/net/28_60. Дата обращения 21.12.2011.

Трофимова Г.Н. Функционирование русского языка в Интернете: концептуально-сущностные доминанты: Дис. ... док. филол. наук. М., 2004.

Crystal D. Language and the Internet. Cambridge, 2001. 